\title{
Effect of Planting Date, Clipping Height, and Cultivar on Forage and Grain Yield of Winter Wheat in Argentinean Pampas
}

\author{
M. J. Arzadún, J. I. Arroquy*, H. E. Laborde, and R. E. Brevedan
}

\begin{abstract}
In Argentinean Pampas, new wheat (Triticum aestivum L.) cultivars are routinely introduced to farmers for dual-purpose production. The objective of this study was to evaluate the effect of planting date, clipping height on forage, and grain yield for wheat cultivars. Treatments were arranged as a $3 \times 3 \times 3$ factorial distributed in a splitsplit plot within a randomized complete block design. Main plots were planting date (March, April, and May); split-plots were clipping height $(3 \mathrm{~cm}, 7 \mathrm{~cm}$, and no clipping); and split-split plots were a facultative cultivar Pincen, and two nonfacultative cultivars Charrua and Bordenave 223 (Bve223). In 1995 and 1996 forage yield decreased in response to a delayed planting date from March to May, whereas in 1997 it was not affected by planting date. The $3-\mathrm{cm}$ clipping height yielded $21 \%$ more forage than plots clipped at $7 \mathrm{~cm}$. Bve223 and Charrua produced significantly more forage than Pincen each year. Grain yield increased as planting date progressed from March to May. Clipping at $3 \mathrm{~cm}$ reduced grain yield compared with no clipping, while during 2 to $3 \mathrm{yr}, 7 \mathrm{~cm}$ produced no significant change in grain yield compared with no clipping. In all years Bve223 produced more grain than Charrua or Pincen. Forage yield lost in response to later planting date ranged between 0 and $81 \%$ during the $3 \mathrm{yr}$; whereas grain yield increased from 40 to $190 \%$ for wheat planted in May compared with March. In conclusion, dual-purpose wheat planted during April had both good forage and grain production, and its success was influenced by cultivars.
\end{abstract}

I $\mathrm{N}$ TEMPERATE, semiarid, and subhumid areas winter crops and livestock production are the main agricultural activities. In Argentinean Pampas, wheat produced for grain accounts for more than $50 \%$ of producer's income (Encuesta Nacional Agropecuaria, 1994). In a typical growing season, fall foraging of winter cereals is the main source of feed for grazing cattle (Bos taurus). Use of winter cereals as a dual-purpose crop (i.e., forage and grain) is practiced at varying levels in several areas of the world. It represents an important contribution to the agricultural economy of the southern Great Plains of the USA (Redmon et al., 1995). It is also practiced in Australia, Morocco, Pakistan, Syria, and Uruguay (Rodriguez et al., 1990).

M.J. Arzadún, Campo Experimetal de Coronel Suárez, Ministerio de Asuntos Agrarios de la Provincia de Buenos Aires, Argentina; J.I. Arroquy, (current address: Instituto Nacional de Tecnología Agropecuaria, Jujuy 850, (4200) Santiago del Estero, Argentina); H.E. Laborde and R.E. Brevedan, Consejo Nacional de Investigaciones Científicas y Técnicas de la República Argentina, Departamento de Agronomía, Universidad Nacional del Sur, San Andrés 800, Bahía Blanca-8000, Argentina, and Centro de Recursos Naturales de Zonas Semiáridas (CERZOS-CONICET), Universidad Nacional del Sur, Bahía Blanca-8000, Argentina. Received 17 Nov. 2005. *Corresponding author (jarroquy@intasgo.gov.ar).

Published in Agron. J. 98:1274-1279 (2006).

Forages

doi:10.2134/agronj2005.0313

(c) American Society of Agronomy

677 S. Segoe Rd., Madison, WI 53711 USA
A dual-purpose crop is a sophisticated crop system that is influenced by many characteristics. Among the factors affecting dual-purpose wheat performance are planting date, intensity of grazing defoliation, cultivars used, and variable weather conditions that can cause interactions between forage and grain production response.

Planting date is one of the most important management factors affecting both forage production and grain yield in winter crops. Total forage yield is highly dependent on growth during the fall. Arzadún (1988) observed that growth rate of oat (Avena sativa L.) planted during early fall was approximately $60 \%$ greater than late fall planting, whereas, plots planted during late fall grew $23 \%$ faster in late winter compared with early fall planted oat. Even though some early studies (Cosia, 1967; Hernández, 1969) have evaluated livestock grazing of winter wheat in Argentina, no information about the effect of planting date and intensity of defoliation on forage production is available for current wheat cultivars.

Winter wheat breeding programs have traditionally selected cultivars based on grain yield when planting occurs during late fall and early winter (mid-May-July). In contrast, dual-purpose wheat cultivars should perform well for both grain and forage production. Some studies have found that grain yield was reduced for wheat planted early and then grazed compared with wheat used for a grain-only system (Holliday, 1956; Hernández, 1969; Redmon et al., 1995). But, other experiments (Christiansen et al., 1989; Redmon et al., 1995) have reported that mechanical clipping (grazing simulation) had minimal effect or, under some circumstances, even increased grain yield.

The objectives of this experiment were to study the effect of planting date, clipping height (grazing simulation), and cultivar on forage production, forage quality, and grain yield for winter wheat grown for dual purposes in the Argentinean Pampas.

\section{MATERIALS AND METHODS}

\section{Experimental Site}

A field experiment was conducted over three growing seasons (1995, 1996, and 1997) at the Experimental Station of the Ministry of Agriculture of Buenos Aires Province at Pasman, Argentina $\left(37^{\circ} 11^{\prime} \mathrm{S}, 62^{\circ} 08^{\prime} \mathrm{W}\right)$. The soil was a Typic Hapludoll (clay loam soil). Soil P content ranged between 12 and $14 \mathrm{mg} \mathrm{kg}^{-1}$; and organic matter (OM) content ranged from 3.2 to $3.5 \%$. Experimental plots consisted of seven rows spaced $0.2 \mathrm{~m}$ apart and $6 \mathrm{~m}$ in length. Only the central $5 \mathrm{~m}^{2}$ of each plot was evaluated. Wheat seeding rate was 275 viable seeds

Abbreviations: ADF, acid detergent fiber; $\mathrm{CP}$, crude protein; DM, dry matter; IVDMD, in vitro dry matter digestibility; NDF, neutral detergent fiber. 
$\mathrm{m}^{-2}$ drill-planted. Each plot received $34 \mathrm{~kg} \mathrm{ha}^{-1}$ of $\mathrm{N}$ from urea at seedling emergence.

\section{Treatments}

Treatments had a $3 \times 3 \times 3$ factorial distribution in a splitsplit plot arrangement within a complete randomized block design (Steel and Torrie, 1980) with four blocks. The main factor was planting date: March (ranged between 14 and 15 March), April (ranged between 12 and 15 April), and May (ranged between 13 and 16 May). The late planting date represented the typical planting date for grain production only. The split plot consisted of three clipping treatments to simulate grazing: clipping at $3 \mathrm{~cm}, 7 \mathrm{~cm}$, and no clipping (control, grain production only). The split-split plots consisted of three wheat cultivars with different morphological and physiological characteristics: Prointa Pincen (Pincen), Buck Charrua (Charrua), and an experimental line, Bordenave 223 (Bve223). Pincen is a typical facultative winter cultivar with a high vernalization requirement, prostrate growth habit, and high tiller production. Charrua is a nonfacultative cultivar without any vernalization requirement and low tiller production. Bordenave 223 is a nonfacultative cultivar with moderate requirement of vernalization and intermediate growth characteristics compared to the other two cultivars.

\section{Forage Sampling and Yield}

To simulate grazing defoliation, plots were mechanically clipped with a power mower (Cortadora de parcelas experimentales Pavicich, Guatimosin, Cordoba, Argentina). With the exception of the last clipping of each season, all clippings were conducted when forage biomass was approximately equal to or greater than $1 \mathrm{t} \mathrm{ha}^{-1}$ using the visual estimation technique of Campbell and Arnold (1973). The last clipping each year was just before onset of Feekes growth stages 5-6 (Large, 1954).

The clipped forage samples were dried at $60^{\circ} \mathrm{C}$ in an aircirculation oven for $48 \mathrm{~h}$. Total forage dry matter (DM) yield was calculated.

Forage samples collected in 1996 and 1997 were analyzed for forage quality at the Laboratory of Animal Nutrition of the Universidad Nacional del Sur (Bahía Blanca, Argentina). Dried samples were ground through a 1-mm screen (no. 4 Wiley Mill, Thomas Scientific, Swedesboro, NJ, USA) in preparation for analysis. Crude protein content was determined using the Kjeldhal procedure described by AOAC (Association of Official Analytical Chemists, 1990). Neutral detergent and acid detergent fiber concentration were determined by Goering and Van Soest (1970) procedure. In vitro DM digestibility was determined by the procedure described by Tilley and Terry (1963). Two fistulated steers (2-yr old) were fed good-quality alfalfa (Medicago sativa L.) hay and were used to supply rumen liquid for IVDMD analysis.

\section{Crop Recovery (Postdefoliation-Anthesis)}

To evaluate crop recovery from the last clipping date to anthesis, crop sunlight interception was measured using a canopy ceptometer (Sunfleck ceptometer, Eijkelkamp, USA). Measurement of crop canopy interception of solar radiation is used to evaluate photosynthetically active radiation captured by the crop (Meek et al., 1984). It serves as a measurement of crop biomass recovery because there is a positive association between biomass accumulation and sunlight interception. A measurement of sunlight interception was conducted at anthesis by performing two determinations per plot by setting the photosensitive bar perpendicular to row direction for the seven rows in each plot. Sunlight interception is reported as a percentage of total solar radiation and was calculated by dividing the value obtained below the canopy by the value for solar radiation above the crop canopy (Wiegand and Richardson, 1984).

\section{Grain Yield}

Grain yield was determined using a small plot combine (Cosechadora Experimental Forti, Argentina), that harvested the five center rows in each plot. Yield components (spikes $\mathrm{m}^{-2}$, kernels spike ${ }^{-1}$, and kernel weight) were evaluated from samples collected from each plot before harvest.

\section{Analysis of Data}

The analysis of variance for multiple years was done using the mixed procedure of SAS (SAS Inst., Cary, NC, USA). Year was treated as a random effect and treatment considered a fixed effect. Additionally, analysis of variance was performed for each year using the mixed procedure. Treatment means were calculated by the LSMEANS option of SAS. Statistical significance was accepted at $P \leq 0.05$. Fisher's protected LSD test was performed to compare means at $P=0.05$.

\section{RESULTS AND DISCUSSION Climatic Conditions}

In the Argentinean Pampas, fall wheat growth is largely determined by precipitation received between late March and early May. Fall precipitation was considered near average for the $3 \mathrm{yr}$ of the study (Table 1 ). Temperatures in winter 1995 were colder than average, whereas in 1996 and 1997 winter temperatures were above average. During 1995 there were 15 more days with freezing temperatures than normally recorded (Table 1). Low temperatures in late-winter 1995 adversely affected regrowth and killed a high proportion of tillers and plants.

Weather conditions during late winter and early spring are very important for initiation of crop recovery growth after winter dormancy. In 1995, the period between late winter and early spring received $132 \mathrm{~mm}$ less precipitation than average. During the postdefoliation period, precipitation in 1996 and 1997 was slightly below the average, 38 and $37 \mathrm{~mm}$, respectively.

\section{Forage Yield}

Forage yield response to planting date was different among years (Table 2). In 1995, forage yield was similar for the March and April planting dates and then declined dramatically for May (Table 2). During 1996, good forage yields were attained for each planting date but as planting date progressed from March to May, yield was less (Table 2). And, in 1997, forage yield was not affected by planting date (Table 2). All cultivars responded to planting date similarly each year with the exception of Charrua in 1995, when it reached its highest DM accumulation, when it was planted in April (data not shown). Autumn growth conditions for 1995 and 1996, were favorable for crop establishment and fall biomass accumulation (rainfall during the period March-April reached 282 and $237 \mathrm{~mm}$ for 1995 and 1996, respectively). In contrast, the period from mid- 
Table 1. Monthly precipitation and number of days with freezing temperature for 1995-1997 and the average for those weather factors for 1971-1990.

\begin{tabular}{|c|c|c|c|c|c|c|c|c|c|}
\hline \multirow[b]{2}{*}{ Season } & \multirow[b]{2}{*}{ Month } & \multicolumn{4}{|c|}{ Rainfall } & \multicolumn{4}{|c|}{ Days with freezing temperature } \\
\hline & & 1995 & 1996 & 1997 & 20-yr avg. $\dagger$ & 1995 & 1996 & 1997 & 20-yr avg. $\dagger$ \\
\hline & & & $-\mathbf{m m}-$ & & 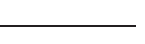 & $\longrightarrow$ & 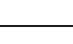 & 1 & 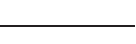 \\
\hline \multirow[t]{2}{*}{ Summer } & January & 52 & 62 & 87 & 123 & - & - & - & - \\
\hline & February & 94 & 124 & 116 & 75 & - & - & - & - \\
\hline \multirow[t]{3}{*}{ Fall } & March & 148 & 98 & 181 & 95 & - & - & - & - \\
\hline & April & 137 & 112 & 30 & 95 & $\mathbf{1}$ & - & - & 2 \\
\hline & May & 0 & 27 & 36 & 61 & $\mathbf{3}$ & 8 & 5 & 7 \\
\hline \multirow[t]{3}{*}{ Winter } & June & 16 & 12 & 108 & 17 & 13 & 17 & 4 & 13 \\
\hline & July & 0 & 32 & 35 & 33 & 25 & 22 & 11 & 14 \\
\hline & August & $\mathbf{0}$ & 31 & 23 & 37 & 18 & 6 & 8 & 11 \\
\hline \multirow[t]{3}{*}{ Spring } & September & $\mathbf{5}$ & 36 & 42 & 67 & 9 & 10 & 6 & 8 \\
\hline & October & 79 & 66 & 90 & 105 & 3 & 2 & - & 2 \\
\hline & November & 175 & 111 & 68 & 91 & - & - & - & \\
\hline Early summer & December & 41 & 169 & 68 & 69 & - & - & - & - \\
\hline
\end{tabular}

$\dagger$ Average of precipitation and number of frost events during 1971-1990 at the Coronel Suárez Meteorological Station.

March to late May 1997 had rainfall that was considerably below average, and as a result, a relatively short period of DM accumulation occurred during late fall compared with 1995 and 1996 seasons. This was compensated for by excellent growing conditions during late winter (108-mm precipitation during June) that resulted in biomass yield for the late planting date to be the same as the earlier dates.

The results observed in this study for forage yield response to planting date for wheat were similar to results reported by others (Holt, 1972; Eplin et al., 2000; Hossain et al., 2003). In dual-purpose cereals, forage yield relies mainly on early autumn and late winter growth (Royo and Tribó, 1997). Thus, variability in weather conditions during those periods similar to what occurred among experimental years in this study can influence the effect of later planting date for forage yield. For instance, in 1997 unfavorable fall weather conditions reduced March and April biomass accumulation compared with the same periods in 1995 and 1996. The results observed in this study agreed with data from $9 \mathrm{yr}$ of research reported by Hossain et al. (2003) that showed only in a few seasons wheat forage yield did not decrease in response to late fall planting date. It has

Table 2. Effect by year of planting date, clipping treatment, and cultivar on forage yield.

\begin{tabular}{|c|c|c|c|}
\hline \multirow[b]{2}{*}{ Variable } & \multicolumn{3}{|c|}{ Year } \\
\hline & 1995 & 1996 & 1997 \\
\hline & \multicolumn{3}{|c|}{$\longrightarrow$ DM, t ha ${ }^{-1}$} \\
\hline Year & 1.88 & 3.15 & 2.20 \\
\hline \multicolumn{4}{|l|}{ Planting date } \\
\hline March & 2.48 & 3.92 & 2.26 \\
\hline April & 2.68 & 3.35 & 2.06 \\
\hline May & 0.48 & 2.20 & 2.27 \\
\hline $\operatorname{LSD}(0.05) \dagger$ & 0.70 & 0.52 & NS \\
\hline \multicolumn{4}{|c|}{ Clipping treatment } \\
\hline $3 \mathrm{~cm}$ & 2.12 & 3.56 & \\
\hline $7 \mathrm{~cm}$ & 1.65 & 2.78 & 2.15 \\
\hline $\operatorname{LSD}(0.05)+$ & 0.45 & 0.38 & NS \\
\hline \multicolumn{4}{|l|}{ Cultivar } \\
\hline Pincen & 1.52 & 2.85 & 1.91 \\
\hline Charrua & 2.04 & 3.25 & 2.26 \\
\hline Bve223 & 2.09 & 3.37 & 2.42 \\
\hline $\operatorname{LSD}(0.05) \S$ & 0.44 & 0.34 & 0.26 \\
\hline
\end{tabular}

$\dagger$ LSD values for planting date effect within each experimental year. + LSD values for clipping treatment effect within each experimental year. § LSD values for cultivar effect within each experimental year. been suggested that wheat generally has a higher rate of growth during winter compared with either oat or barley (Hordeum vulgare L.) (Gardner and Rogers, 1956; Day and Tucker, 1959). Higher growth rate of wheat during winter may partially overcome the reduction in forage biomass production caused by late-fall planting dates.

In 1995 and 1996, plots clipped at $3 \mathrm{~cm}$ produced more forage than plots clipped at $7 \mathrm{~cm}$ (Table 2). The loss in forage yield at $7 \mathrm{~cm}$ was greater for Pincen and Bve223 compared with Charrua (data not shown). Clipping treatments did not significantly affect forage yield in 1997 (Table 2).

The effect of clipping height on winter pastures has been variable. Many studies have reported a reduced forage yield in response to lower clipping heights (Johnston, 1961; Binnie and Harrinton, 1972). Others (Dalrymple, 1995; Arzadún et al., 1997) have observed either greater or equal forage yield for lower clipping heights compared to higher clipping heights of cereals. The results in this study agree with the information reported by those two authors.

On average, forage yield was $23 \%$ greater for Bve 223 and Charrua (Table 2) than Pincen. Forage yield for Pincen and Bve223 decreased as planting date became later. The variability of response observed for Charrua may be due to its lack of vernalization requirement. In general, cultivars with erect growth habit, such as Charrua, are characterized by frost intolerance and a low vernalization requirement (Davidson et al., 1985). The severe winter in 1995 resulted in reduced forage yield as planting date became later for Charrua compared with the other two cultivars. Reduced forage yield for Charrua was not only associated with severe winter conditions but also was attributed to early jointing due to highly favorable fall growing conditions before winter's onset.

\section{Forage Quality}

Forage quality analyses were only performed on 1996 and 1997 samples. In vitro dry matter digestibility was high for all cultivars and planting dates (avg. $747 \pm 93 \mathrm{~g}$ $\mathrm{kg}^{-1} \mathrm{DM}$ ) during both years, but did not differ among treatments. Acid detergent fiber also had considerable variability for clipping treatments and cultivars. Overall 
Table 3. Effect by year of planting date, clipping treatment, and cultivar on grain yield.

\begin{tabular}{|c|c|c|c|}
\hline \multirow[b]{2}{*}{ Variable } & \multicolumn{3}{|c|}{ Year } \\
\hline & 1995 & 1996 & 1997 \\
\hline & \multicolumn{3}{|c|}{$\mathrm{tha}^{-1}$} \\
\hline \multirow{2}{*}{\multicolumn{4}{|c|}{ Planting date }} \\
\hline & & & \\
\hline March & 0.64 & 1.47 & 1.13 \\
\hline April & 1.21 & 1.54 & 1.56 \\
\hline May & 1.86 & 2.06 & 1.92 \\
\hline $\operatorname{LSD}(\mathbf{0 . 0 5}) \dagger$ & 0.86 & 0.52 & 0.53 \\
\hline \multicolumn{4}{|c|}{ Clipping treatment } \\
\hline $3 \mathrm{~cm}$ & 1.17 & 1.50 & 1.36 \\
\hline $7 \mathrm{~cm}$ & 1.15 & 1.67 & 1.57 \\
\hline No clipping & 1.40 & 1.91 & 1.69 \\
\hline $\operatorname{LSD}(0.05)+$ & 0.12 & 0.31 & 0.26 \\
\hline \multicolumn{4}{|l|}{ Cultivar } \\
\hline Pincen & 1.18 & 1.73 & 1.30 \\
\hline Charrua & 1.13 & 1.69 & 1.67 \\
\hline Bve223 & 1.41 & 1.65 & 1.65 \\
\hline LSD $(0.05) \S$ & 0.08 & NS & 0.09 \\
\hline
\end{tabular}

$\dagger$ LSD values for planting date effect within each experimental year. \$LSD values for clipping treatment effect within each experimental year. § LSD values for cultivar effect within each experimental year.

ADF decreased as planting date became later (251, 239, and $226 \mathrm{~g} \mathrm{~kg}^{-1} \mathrm{DM}$ for March, April, and May, respectively). Clipping treatment $\times$ cultivar interaction was significant $(P<0.01)$ for forage NDF. Pincen had lower NDF at 3-cm compared with 7-cm clipping height. Clipping height did not affect NDF for Charrua and Bve223. In general NDF decreased in response to later planting date $\left(503,484\right.$, and $473 \mathrm{~g} \mathrm{~kg}^{-1} \mathrm{DM}$ for March, April, and May, respectively). Finally, CP averaged across years was higher for May planting date than March and April (198 vs. $182 \mathrm{~g} \mathrm{~kg}^{-1}$ DM for May vs. March and April, respectively). The lower forage quality observed for early and midplanting dates appeared to be associated with a higher incidence of leaf rust (Puccinia recondita) that occurred with earlier planting dates. In a 3-yr grazing study on wheat pasture, Arzadún et al. (2003) observed a high correlation between leaf rust severity and forage quality traits. In other studies, it has also been observed (Jain and Pelletier, 1958; Krog et al., 1961) that foliar dis- eases decrease highly digestible components of the forage, such as soluble sugars and soluble protein, reducing nutritive value.

\section{Grain Yield}

Grain yield, in all experimental years, increased as planting date went from March to May (Table 3). In 1995, the increase in grain yield in response to later planting date was attributed to increases in kernel weight and kernels per spike, but number of spikes per square meter did not significantly change (Table 4). In contrast, in 1996 and 1997 the impact of later planting date on grain yield was associated with a significant increase in all yield components (Table 4), with the exception of kernel weight for 1996 that did not change as planting date became later. In all experimental years, crop interception of sunlight at anthesis increased (Table 5) as planting date changed from March to May. The effect of planting date on grain yield was related to the ability of the crop to recover its leaf area after clipping.

Grain yield was significantly different among years (Table 3). Grain yield did not differ between 3- and 7-cm clipped treatments (Table 3). Clipping height at $3 \mathrm{~cm}$ reduced grain production compared with no clipping, whereas 7-cm clipping height did have a minimal reduction on grain yield compared with unclipped treatments except for 1995. This was associated with changes in yield components. For instance, in 1995 clipping depressed grain kernel weight but did not affect number of spikes per square meter and number of kernels per spike (Table 4). Meanwhile, in 1996 the negative impact of clipping on grain yield was only attributed to a decrease in the number of spikes per square meter. In 1997 clipping significantly reduced all yield components. Furthermore, the effect of clipping on grain yield and yield components was attributed to a significant reduction in sunlight crop interception at anthesis for 1996 and 1997 for both clipped treatments (Table 5).

Others doing clipping studies (Davidson et al., 1985; Krenzer, 1995; Royo and Tribó, 1997) have reported

Table 4. Effect of planting date, clipping height, and cultivar on yield components for 1995, 1996, and 1997.

\begin{tabular}{|c|c|c|c|c|c|c|c|c|c|}
\hline \multirow[b]{2}{*}{ Variable } & \multicolumn{3}{|c|}{ Spike $\mathbf{m}^{-2}$} & \multicolumn{3}{|c|}{ Kernel spike $^{-1}$} & \multicolumn{3}{|c|}{ Kernel weight } \\
\hline & 1995 & 1996 & 1997 & 1995 & 1996 & 1997 & 1995 & 1996 & 1997 \\
\hline & & & & & & & & $-\mathbf{m g}$ & $\overline{-}$ \\
\hline \multirow{2}{*}{\multicolumn{10}{|c|}{$\begin{array}{l}\text { Year } \\
\text { Planting date }\end{array}$}} \\
\hline & & & & & & & & & \\
\hline March & 329 & 231 & 212 & 13.7 & 26.5 & 24.8 & 27.2 & 35.1 & 32.4 \\
\hline April & 340 & 240 & 232 & 18.6 & 27.2 & 30.3 & 33.0 & 33.9 & 32.7 \\
\hline May & 337 & 291 & 243 & 29.6 & 30.9 & 30.4 & 38.3 & 33.5 & 37.4 \\
\hline LSD $(0.05) \dagger$ & NS & 29 & 21 & 5.5 & 2.9 & 3.4 & 3.5 & NS & 1.5 \\
\hline \multicolumn{10}{|c|}{ Clipping treatment } \\
\hline $3 \mathrm{~cm}$ & 253 & 233 & 207 & 20.1 & 27.8 & 23.9 & 30.4 & 34.1 & 31.4 \\
\hline $7 \mathrm{~cm}$ & 363 & 254 & 215 & 19.4 & 28.1 & 30.0 & 30.7 & 33.6 & 33.7 \\
\hline No clipping & 372 & 275 & 265 & 22.5 & 28.6 & 31.5 & 37.4 & 34.8 & 37.3 \\
\hline $\operatorname{LSD}(0.05) \div$ & 42 & 22 & 17 & NS & NS & 3.0 & 1.9 & NS & 1.4 \\
\hline \multicolumn{10}{|l|}{ Cultivar } \\
\hline Pincen & 343 & 270 & 239 & 21.5 & 28.6 & 28.3 & 29.8 & 33.7 & 28.8 \\
\hline Charrua & 342 & 262 & 240 & 19.9 & 28.3 & 29.4 & 28.7 & 34.2 & 34.6 \\
\hline Bve223 & 323 & 258 & 221 & 20.5 & 27.6 & 27.8 & 40.0 & 34.6 & 39.1 \\
\hline $\operatorname{LSD}(0.05) \S$ & NS & NS & 15 & NS & NS & NS & 1.8 & NS & 1.2 \\
\hline
\end{tabular}

$\dagger$ LSD values for planting date effect within each experimental year.

$\$$ LSD values for clipping treatment effect within each experimental year.

$\S$ LSD values for cultivar effect within each experimental year. 
Table 5. Effect by year of planting date, clipping height, and cultivar on interception of solar radiation at anthesis.

\begin{tabular}{|c|c|c|c|}
\hline \multirow[b]{2}{*}{ Variable } & \multicolumn{3}{|c|}{ Years } \\
\hline & 1995 & 1996 & 1997 \\
\hline & \multicolumn{3}{|c|}{ sunlight crop interception, $\%$} \\
\hline Year & 51.7 & 52.3 & 64.5 \\
\hline \multicolumn{4}{|l|}{ Planting date } \\
\hline March & 44.1 & 44.0 & 54.5 \\
\hline April & 51.0 & 47.1 & 66.9 \\
\hline May & 60.1 & 65.9 & $\mathbf{7 2 . 0}$ \\
\hline $\mathbf{L S D}(0.05) \dagger$ & 11.6 & 5.9 & 5.4 \\
\hline \multicolumn{4}{|c|}{ Clipping treatment } \\
\hline $3 \mathrm{~cm}$ & 31.8 & 34.7 & 50.2 \\
\hline $7 \mathrm{~cm}$ & 59.4 & 35.4 & 57.6 \\
\hline No clipping & 63.9 & 87.0 & 85.6 \\
\hline $\operatorname{LSD}(0.05) \uparrow$ & 7.5 & 5.3 & 4.9 \\
\hline \multicolumn{4}{|l|}{ Cultivar } \\
\hline Pincen & 58.2 & 54.2 & 62.5 \\
\hline Charrua & 40.2 & 51.0 & 66.3 \\
\hline Bve223 & 56.1 & 51.9 & 64.7 \\
\hline $\operatorname{LSD}(0.05) \S$ & 6.9 & NS & NS \\
\hline
\end{tabular}

$\dagger$ LSD values for planting date effect within each experimental year.

$\doteqdot$ LSD values for clipping treatment effect within each experimental year.

$\S$ LSD values for cultivar effect within each experimental year.

suppression of grain yield similar to our results. Although an earlier planting date achieves greater biomass accumulation at anthesis, an important proportion of this biomass is plant tissues with low photosynthetic activity (Dunphy et al., 1982). Moreover, Winter and Musick (1993) observed that early planting date had a yield-reducing effect on grain yield due to a longer vegetative period that reduced soil water availability before anthesis. It is also possible that the longer vegetative period for early planted wheat causes a $\mathrm{N}$ deficiency for grain production. In addition, forage removal resulted in a significant extraction of soil $\mathrm{N}$ reducing the availability of $\mathrm{N}$ for grain production (Thomason et al., 2000). The reduction in sunlight interception (lower biomass at anthesis) observed for early planting dates is probably associated with the inability of the crop to recover the leaf area required to maximize grain yield. Thus, reductions in grain yield for clipped wheat is attributed to planting date, grazing intensity (clipping treatments), and $\mathrm{N}$ deficiency caused by the large amount of forage removal for the early planting dates.

In addition, early vs. late planting dates for wheat produce differences in canopy structure (Veneklaas and Van Den Boogaard, 1994). Early planted wheat should have older leaves that have lower photosynthetic activity than later planted wheat. This difference may affect the ability for crop recovery before anthesis after the last respective clipping date for early and late planted wheat. Lambers et al. (1998) suggested that when carbohydrates become part of the structural carbohydrates matrix of the plant, they are unable to be mobilized for grain fill.

In 1995, Bve223 produced more grain than Pincen and Charrua (Table 3). This difference was attributed to higher kernel weight (Table 4) for Bve223. In 1996 the cultivars did not differ in grain yield nor did they have differences in yield components. In 1997 Bve223 and Charrua both produced more (Table 3) grain than Pincen. The Bve223 had less spikes per square meter than Pincen, but it more than compensated for this with

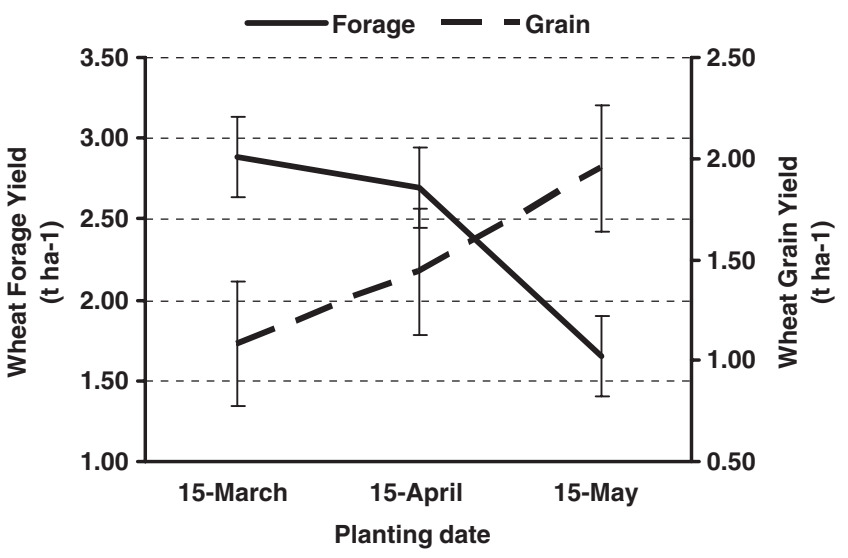

Fig. 1. Effect of planting date on forage and grain yield. Vertical bars represent $\mathrm{SE}$ of means. The $\mathrm{SE}$ of the estimates were 0.25 and $0.31 \mathrm{t}$ for forage and grain yield, respectively.

greater kernel weight. Charrua had greater kernel weight. Even though Charrua had a similar yield to that for Bve223 in 1997, the former cultivar exhibited early onset of jointing for early planting dates that may limit its utilization as a dual-purpose crop. The Bve223 had greater grain yield than Charrua and Pincen without the occurrence of early jointing.

This experiment demonstrated a major effect of planting date on grain yield in a dual-purpose wheat crop. The yield response generated by the effect of planting date was always greater than the response due to either defoliation or cultivar treatments.

\section{CONCLUSIONS}

Total forage yield for dual-purpose wheat decreased in response to later planting date while grain yield increased (Fig. 1). On average, for each planting day delay between 15 March and 15 May, forage yield decreased approximately $20 \mathrm{~kg} \mathrm{ha}^{-1}$ and grain yield increased $14 \mathrm{~kg} \mathrm{ha}^{-1}$. However, yearly weather conditions greatly impacted the magnitude of forage yield change (ranged between 0 and $81 \%$ ) with later planting date. Grain yield decrease in response to early planting date ranged between 28 and $65 \%$ less compared with a May planting date. Based on this study the most optimum planting date for dual-purpose wheat appears to be during April, because both forage and grain yield were less reduced compared with earlier and later planting date. Clipping height (grazing intensity) at $7 \mathrm{~cm}$ has good forage yield while maintaining good grain yield, and as a dual-purpose wheat Bve223 performs better than Charrua and Pincen.

\section{ACKNOWLEDGMENTS}

We would like to express our thanks to Silvia Canelo and Rosana Palomo (UNS-Laboratorio de Nutrición Animal) for the laboratory work. Financial support for this research came in part from Consejo Nacional de Investigaciones Científicas y Técnicas of Argentina (Project no. 08-04516).

\section{REFERENCES}

Association of Official Analytical Chemists. 1990. Official methods of analysis: First supplement. 15th. ed. AOAC, Arlington, VA. 
Arzadún, M.J. 1988. Curvas de producción de verdeo de invierno. Revista Argentina de Producción Animal. 8(Suppl. 1):90-91.

Arzadún, M.J., M.H. Vallejos, and M.M. Piersanti. 1997. Effect of frequency and intensity of defoliation on oat-vetch mixture. p. 137138. In Proc. Grassl. 18th Int. Grassl. Congr., Winnipeg and Saskatoon, Canada. 8-17 June 1997. Can. Forage Counc., Can. Soc. Anim. Sci.

Arzadún, M.J., J.I. Arroquy, H.E. Laborde, and R.E. Brevedan. 2003. Grazing pressure on beef and grain production of dual-purpose wheat in Argentina. Agron. J. 95:1157-1162.

Binnie, R.C., and F.J. Harrinton. 1972. The effect of cutting height and cutting frequency on the productivity of an Italian ryegrass sward. J. Br. Grassl. Soc. 27:177-182.

Campbell, N.A., and G.W. Arnold. 1973. The visual assessment of pasture yield. Aust. J. Exp. Agric. Anim. Husb. 63:263-267.

Christiansen, S., T. Svejcar, and W.A. Phillips. 1989. Spring and fall cattle grazing effects on components and total grain yield of winter wheat. Agron. J. 81:145-150.

Cosia, A.A. 1967. Economía de los cereales de doble propósito. Informe Técnico no. 57. EEA INTA Pergamino.

Dalrymple, R.L. 1995. Rotational grazing of small grain pasture. Oklahoma Ext. Serv. Publ. no. 19.

Day, A.D., and T.C. Tucker. 1959. Forage production of small grains under maximum favorable conditions. Agron. J. 51:569-572.

Davidson, R.L., K.R. Christian, D.B. Jones, and P.M. Bremner. 1985 Responses to wheat to vernalization and photoperiod. Aust. J. Agric. Res. 36:347-359.

Dunphy, D.J., M.E. McDaniel, and E.C. Holt. 1982. Effects of forage utilization on wheat grain yield. Crop Sci. 22:106-109.

Eplin, F.M., I. Hossain, and E.G. Krenzer. 2000. Winter wheat fallwinter forage yield and grain yield response to planting date in a dual- purpose system. Agric. Syst. 63:161-173.

Encuesta Nacional Agropecuaria. 1994. Instituto Nacional Estadisticas y Censos Rep. Argentina. INDEC, Ministerio de Economia de la Republica, Argentina.

Gardner, F.P., and T.H. Rogers. 1956. Seasonal and yearly production of annual winter grasses and grass-legume combinations for temporary winter grazing in Georgia. Agron. J. 48:546-551.

Goering, H.K., and P.J. Van Soest. 1970. Forage fiber analyses (apparatus, reagents, procedures and some applications). Agric. Handb. 379. U.S. Gov. Print. Office, Washington, DC.

Hernández, O. 1969. Efecto de la época de siembra e intensidad del pastoreo sobre el rendimiento en grano de trigo doble propósito. Rev. Invest. Agric. 6:155-165.

Holliday, R. 1956. Fodder production from winter-sown cereals and its effect upon grain yield. Field Crops 9:207-213.
Holt, E.C. 1972. Growth behavior and management of small grains for forage. Agron. J. 54:272-275.

Hossain, I., F.M. Eplin, and E.G. Krenzer, Jr. 2003. Planting date influence on dual-purpose wheat forage yield, grain yield, and test weight. Agron. J. 95:1179-1188.

Jain, A.C., and R.L. Pelletier. 1958. Effects of rust infection on the carbohydrate metabolism of wheat seedlings. Nature 182:882-883.

Johnston, A. 1961. Comparison of lightly grazed and ungrazed range in the fescue grassland of southwestern Alberta. Can. J. Plant Sci. 41:615-622.

Krenzer, E.G. 1995. Economics, cultivar selection, and management practices for dual purpose wheat. p. 185-202. In Proc. Int. Workshop on Facultative and Double Purpose Wheat, La Estanzuela, Colonia, Uruguay, Oct. 1995. INIA, Colonia, Uruguay.

Krog, N.E., L. Le Tourneau, and H. Hart. 1961. The sugar content of wheat leaves infected with stem rust. Phytopatology 20:75-77.

Lambers, H., F. Suart, and L. Pons. 1998. Plant physiological ecology. Springer, New York.

Large, E.C. 1954. Growth stages in cereals. Plant Pathol. 3:128-129.

Meek, D.W., J.L. Hatfield, T.A. Howell, S.B. Idso, and R.J. Reginato, 1984. A generalized relationship between photosynthetically active radiation and solar radiation. Agron. J. 76:939-945.

Redmon, L.A., G.W. Horn, E.G. Krenzer, and D.J. Bernardo. 1995. A review of livestock grazing and wheat grain yield: Boom or bust? Agron. J. 87:137-147.

Rodriguez, A., J.N. Trapp, O.L. Walker, and D.J. Bernardo. 1990. A wheat grazing systems model for the US Southern Plains: I. Model description and performance. Agric. Syst. 33:41-59.

Royo, C., and F. Tribó. 1997. Triticale and barley for grain and for dualpurpose (forage + grain) in a Mediterranean-type environment: I. Growth analysis. Aust. J. Agric. Res. 48:411-421.

Steel, R.G.D., and J.H. Torrie. 1980. Principles and procedures of statistics. 2nd ed. McGraw-Hill Book Company, New York.

Thomason, W.E., W.R. Raun, and G.V. Johnson. 2000. Winter wheat fertilizer nitrogen use efficiency in grain and forage production systems. J. Plant Nutr. 23:1505-1516.

Tilley, J.M., and R.A. Terry. 1963. A two-stage technique or the in vitro digestion of forage crops. J. Br. Grassl. Soc. 18:104-118.

Veneklaas, E., and R. Van Den Boogaard. 1994. Leaf age-structure effects on plant water use and photosynthesis of two wheat cultivars. Plant Physiol. 54:331-337.

Wiegand, C.L., and A.J. Richardson. 1984. Leaf area, light interception, and yield estimates from spectral components analysis. Agron. J. 76:543-548

Winter, S.R., and J.T. Musick. 1993. Wheat planting date effects on soil water extraction and grain yield. Agron. J. 85:912-916. 